\title{
Regal Jumping Spider, Phidippus regius C. L. Koch (Arachnida: Salticidae) ${ }^{1}$
}

\author{
G. B. Edwards ${ }^{2}$
}

\section{Introduction}

Except for two pantropical species (Edwards 1979), the jumping spider most frequently encountered in Florida is Phidippus regius C.L. Koch. This species is aptly named in terms of its size, as it is the largest jumping spider in eastern North America. The species is found in the southeastern U.S., the Greater Antilles, and the Bahamas, but is most common in peninsular Florida.

\section{Abbreviated Synonymy}

Phidippus regius C.L. Koch, 1846

Salticus sagraeus Lucas, 1857

Attus miniatus Peckham \& Peckham, 1883

Phidippus tullgreni Wallace, 1950

\section{Description}

Adult males of $P$. regius average $12 \mathrm{~mm}$ in length (range 6 to $18 \mathrm{~mm}$ ). Males are always black with alternating black and white fringes on the first pair of legs; on the dorsum of the abdomen are a white basal band, a central triangular white spot, and a pair of oval white spots posteriorly. The paired chelicerae are enlarged and iridescent (green-blue-violet); each has a subdistal tubercle on its anterior face. The first legs of larger males are disproportionately longer than smaller males, a type of allometry.

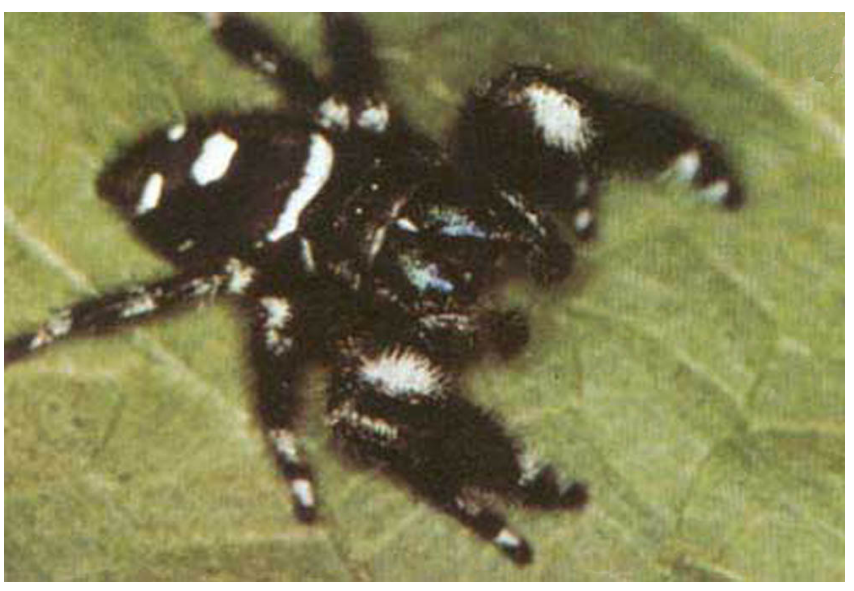

Figure 1. Adult male regal jumping spider, Phidippus regius C.L. Koch. Credits: G. B. Edwards, Division of Plant Industry

1. This document is EENY-152 (originally published as DPI Entomology Circular 223), one of a series of Featured Creatures from the Entomology and Nematology Department, Florida Cooperative Extension Service, Institute of Food and Agricultural Sciences, University of Florida. Published: September 2000. This document is also available on Featured Creatures Website at http://creatures.ifas.ufl.edu. Please visit the EDIS Website at http://edis.ifas.ufl.edu. Additional information on these organisms, including many color photographs, is available at the Entomology and Nematology Department website at http://entnemdept.ifas.ufl.edu/.

2. G. B. Edwards, Florida Department of Agriculture and Consumer Services, Division of Plant Industry, Gainesville, FL.

The Institute of Food and Agricultural Sciences is an equal opportunity/affirmative action employer authorized to provide research, educational information and other services only to individuals and institutions that function without regard to race, color, sex, age, handicap, or national origin. For information on obtaining other extension publications, contact your county Cooperative Extension Service office. Florida Cooperative Extension Service/Institute of Food and Agricultural Sciences/University of Florida/Christine Taylor Waddill, Dean. 
Adult females average $15 \mathrm{~mm}$ in length (range 7 to $22 \mathrm{~mm}$ ). Females may have the same color pattern as males, but usually females have the black dorsal areas of the body covered with colored scales. These scales may be gray, tan, brown, orange, or combinations of any or all of the above colors. Those females that are completely covered with orange scales are particularly attractive. Most of the more colorful females are found in the southern two-thirds of Florida and in the Greater Antilles. Cheliceral color is iridescent (either green or red- violet), but less noticeable than in males because the chelicerae are usually covered by the palpi, small leg-like appendages which are densely covered with long white setae. The cheliceral tubercles are absent. Leg-fringes are present, but not as distinct as in males. Females also have four tufts of setae in the region of the dorsal eyes; males lack these tufts.

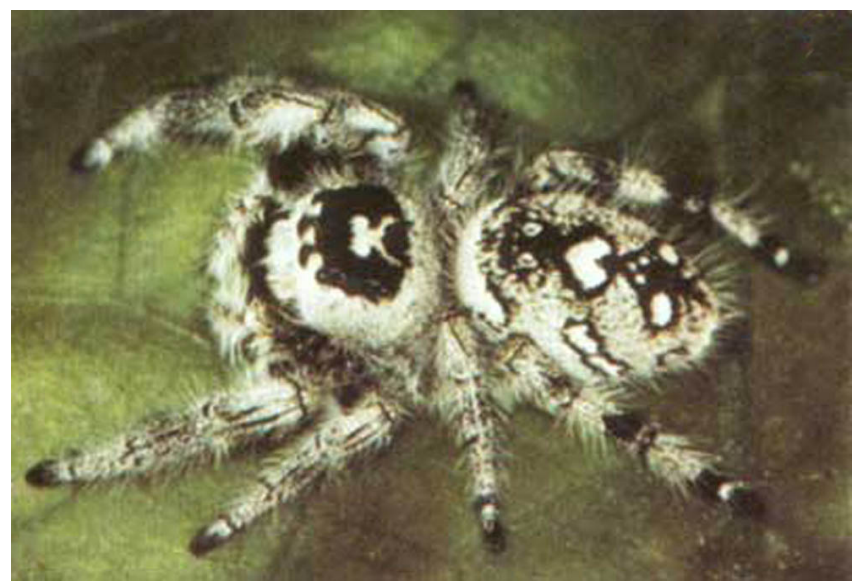

Figure 2. Adult female, gray form, regal jumping spider, Phidippus regius C.L. Koch. Credits: G. B. Edwards, Division of Plant Industry

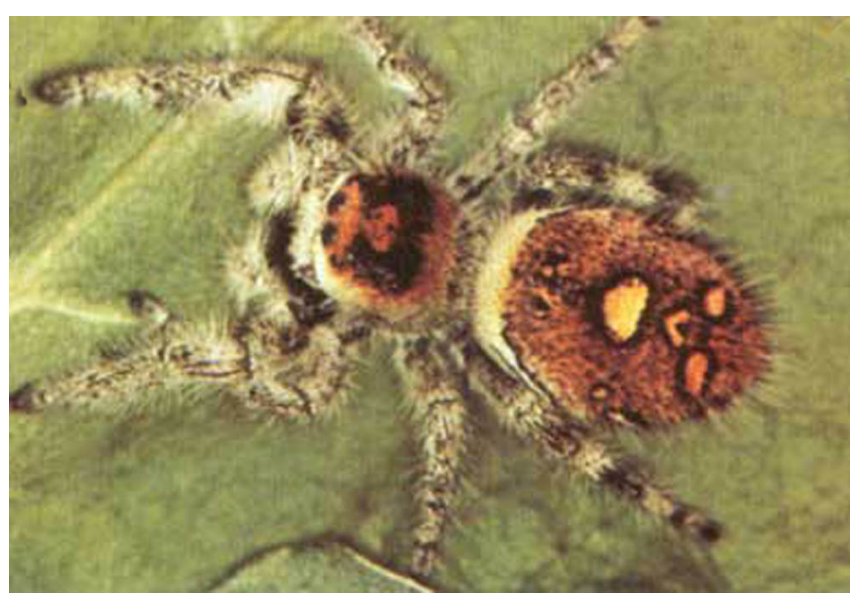

Figure 3. Adult female, orange form, regal jumping spider, Phidippus regius C.L. Koch. Credits: G. B. Edwards, Division of Plant Industry
Phidippus regius is one of the few spiders that can be sexed in the early instars. Juvenile females of more southern populations attain a scale cover as early as the 3rd instar; males are stark black and white throughout their life cycle.

\section{Identification}

Jumping spiders can be recognized easily by their eye arrangement. The eyes are arranged in three rows: The 1st row contains four eyes, the two large median eyes and two smaller lateral eyes; the 2nd row contains two tiny eyes; and the 3rd row contains two small eyes. The species of Phidippus can be recognized because they are the largest, hairiest salticids in the region, and their iridescent chelicerae just below the front eyes are very conspicuous. Two close relatives of $P$. regius, $P$. audax (Hentz) and $P$. otiosus (Hentz), occur throughout most of the range of $P$. regius and are similar in appearance. The three species can be separated by the following key:

1. Posterior abdominal spots orange and quadrangular......... P. otiosus

1'. Posterior abdominal spots white and not quadrangular ........... 2

2. Posterior abdominal spots oval, black spots absent ............ regius

2'. Posterior abdominal spots linear, 4 pair of dull black, quadrangular spots on dorsum of abdomen ........... P. audax

\section{Habits and Habitat}

Phidippus regius is found in most field and open woodland habitats, but not within mature hardwood forest. Smaller immatures usually are found in the herbaceous zone, but subadults and particularly adults favor palms and palmettoes in semiarid habitats. Where palms are absent, shrubs and trees are inhabited by the older stages. Adults seem to prefer substrates with relatively monoplanar surfaces and are frequently found on walls of buildings (Edwards 1980).

As with all jumping spiders, $P$. regius uses its excellent vision to locate prey and potential mates. Prey is caught by jumping on it, hence the common 


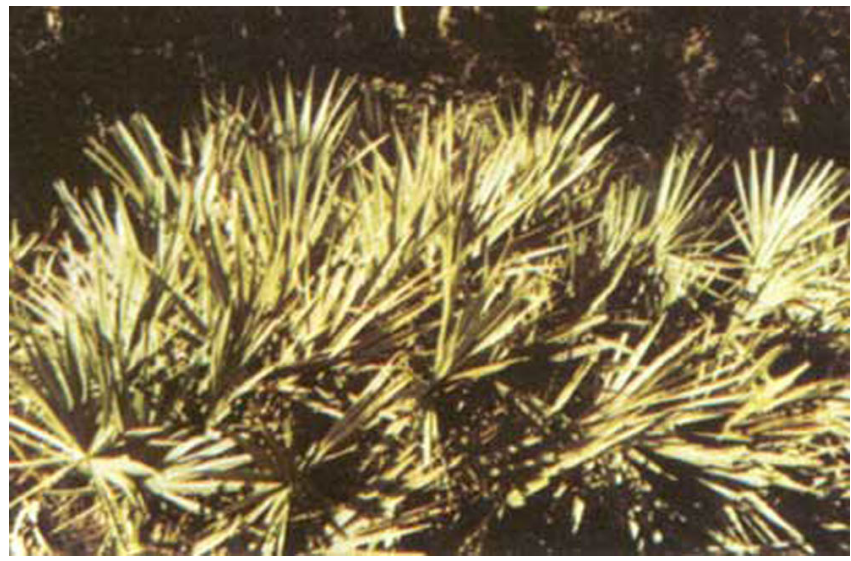

Figure 4. Saw palmetto, a typical substrate for the regal jumping spider, Phidippus regius C.L. Koch. Credits: G. B. Edwards, Division of Plant Industry

name of the family. Males court females with a species-specific dance in which the leg fringes are displayed (Edwards 1975). The chelicerae are also believed to be of use in recognition between the sexes, as no other jumping spiders within the geographic range of the genus Phidippus have iridescent chelicerae.

Although jumping spiders do not make webs to capture prey, they do use silk. Hunting spiders trail a dragline behind them to break their fall in case they miss a jump. Silken nests, ellipsoid structures with an opening at each end, are used for resting at night, molting, and egg-laying. Juveniles may make their nests in the tops of herbs or in rolled leaves, while subadults and adults frequently make their nests along the inner mid-veins of palm fronds. Adult males often cohabit with subadult and occasionally adult females in order to mate. A cohabiting male will mate with a subadult female soon after she matures. Jackson (1977) showed that males of P. johnsoni (Peckham $\&$ Peckham) were able to employ a tactile type of courtship to females inside nests, which was much different than the visually-oriented courtship males employed for females outside nests. A similar tactile courtship has been noted for $P$. regius, $P$. cardinalis (Hentz), and $P$. whitmani Peckham \& Peckham (Edwards 1980). Other species of Phidippus, including P. audax (Hentz), P. clarus Keyserling (Snetsinger 1955), and P. otiosus (Hentz) (Hill 1978) are known to cohabit.

Females of $P$. regius make thick silken nests under the bark of various trees, particularly oak and pine, in which to lay their eggs. Cracks and spaces in old houses and barns also provide suitable shelter for nests of egg-laying females. Females lay up to four batches of eggs; the 1st batch averages 183 eggs, the number of eggs declining with each successive batch. Assuming a female laid four batches of eggs, the average total of all batches was 402 eggs, but the maximum egg production was calculated at 715 eggs (Edwards 1980). Even this total might underestimate the maximum reproductive potential of $P$. regius, since Anderson (1978) reported a large female to lay a single eggsac with 570 eggs.

Phidippus regius individuals are known to feed on a wide variety of other arthropods. Smaller immatures feed heavily on Diptera, while older juveniles and adults feed on large Orthoptera and Hemiptera, and larval and adult Lepidoptera (Edwards 1980). A male of P. regius was collected while feeding on an adult of Diaprepes abbreviatus (Linnaeus), a pest of citrus and sugarcane (D. Gowan, collector).

\section{Survey and Detection}

Phidippus regius is a common spider in peninsular Florida. The first impression made upon the casual observer is of a moderately large, black, hairy spider; to the uninformed, this impression leads naturally to the conviction that the spider is a black widow. The black widow, however, is a globose, shiny black spider with long, spindly legs that is not noticeably hairy at all. Jumping spiders are harmless, beneficial creatures. The larger species, such as $P$. regius, are capable of delivering a painful bite, but will do so only if held tightly. The bite itself causes a sharp stinging sensation which subsides in a few minutes and requires no treatment. These spiders are easily tamed and can be induced to jump back and forth from hand to hand.

\section{Selected References}

Anderson, J.F. 1978. Energy content of spider eggs. Oecologia 37: 41-57.

Edwards, G.B. 1975. Biological studies on the jumping spider, Phidippus regius C.L. Koch. M.S. thesis, University of Florida. 64 p. 
Edwards, G.B. 1979. Pantropical jumping spiders occurring in Florida (Araneae: Salticidae). Fla. Dept. Agric. Cons. Serv. DPI Ent. Circ. 199: 1-4.

Edwards, G.B. 1980. Taxonomy, ethology, and ecology of Phidippus (Araneae: Salticidae) in eastern North America. Ph.D. dissertation, University of Florida. 354 p.

Hill, D.E. 1978. The behavior of Eris marginata (Araneae: Salticidae). Peckhamia 1: 63-70.

Jackson, R.R. 1977. Courtship versatility in the jumping spider Phidippus johnsoni (Araneae:

Salticidae). Anim. Behav. 25: 953-957.

Koch, C.L. 1846. Die Arachniden, Vol. 13, Nurnberg $234 \mathrm{p}$.

Lucas, H. 1857. Aragnides, in Ramon de la Sagra, Historia fisica, politica y natural de la Isla de Cuba. Vol. 7, part 2, Paris. pp. xxiv-xxx.

Peckham, G.W., and E.G. Peckham. 1883. Descriptions of new or little known spiders of the family Attidae from various parts of the United States of North America. Milwaukee 1883: 1- 35.

Snetsinger, R. 1955. Observations on two species of Phidippus. Ent. News 66: 9-15.

Wallace, H.K. 1950. On Tullgren's Florida spiders. Florida Ent. 33: 71-83. 